\title{
Congress prepares compromise plan to save Landsat, lower costs and improve service
}

\begin{abstract}
Washington. Landsat, the remote-sensing satellite programme whose move several years ago from the government to the private sector has been a case study in misguided privatization, may have won a new lease of life. A hard-fought compromise between federal agencies, environmental groups and Landsat's commercial operators is expected to return the programme's operations to the government, paving
\end{abstract} the way for a seventh orbiter and giving scientists renewed access to the data at minimal cost.

Early this week, Congress was putting the final touches to an agreement - a combination of a bill authorizing Landsat operations and data and appropriating money for a Landsat 7 orbiter in both the National Aeronautics and Space Administration (NASA) and Department of Defense (DOD) budgets for next year - that could be passed in the few remaining days before Congress adjourns. The last hurdle is approval from EOSAT, the company that now runs the Landsat programme.

If passed, the legislation would represent the end of the decade-long experiment in commercializing the Landsat programme. After years of losing money under government supervision, Landsat was transferred to EOSAT in 1986 as part of a series of such initiatives by President Ronald Reagan. But privatization was not the answer. Since 1982, when Reagan first tried to get the programme to pay for itself, prices have risen from $\$ 600$ to more than $\$ 4,000$ per image, and annual sales of images to the university research sector have dropped from 34,000 to just a few hundred. Landsat has also faced increased competition from the French SPOT satellites and projects by Japan and the European Space Agency.

The quality and availability of the data have suffered with the age of the Landsat 4 and 5 orbiters, launched in the early 1980s. Even those researchers who have been able to afford the images say that many of them are unreadable or are lost because they were recorded on used magnetic tape. Kevin Price, a University of Kansas geographer, rejected 13 of the 17 images he received last year. Others complain of waiting as long as four months for data and say that they often find it easier to hire a small aircraft to photograph the desired area. "Landsat's been nothing but heartache for us in the universities," says Price.

Users are particularly disturbed by EOSAT's policy of accumulating data only

when there may be a market for them, making it difficult for users to purchase old data that they have not already asked EOSAT to acquire. Data-acquisition rates have dropped by 20 per cent (or more) a year for the past three years, leaving large gaps in the available data and making them almost useless for scientists who want to examine recent climate records or environmental trends.

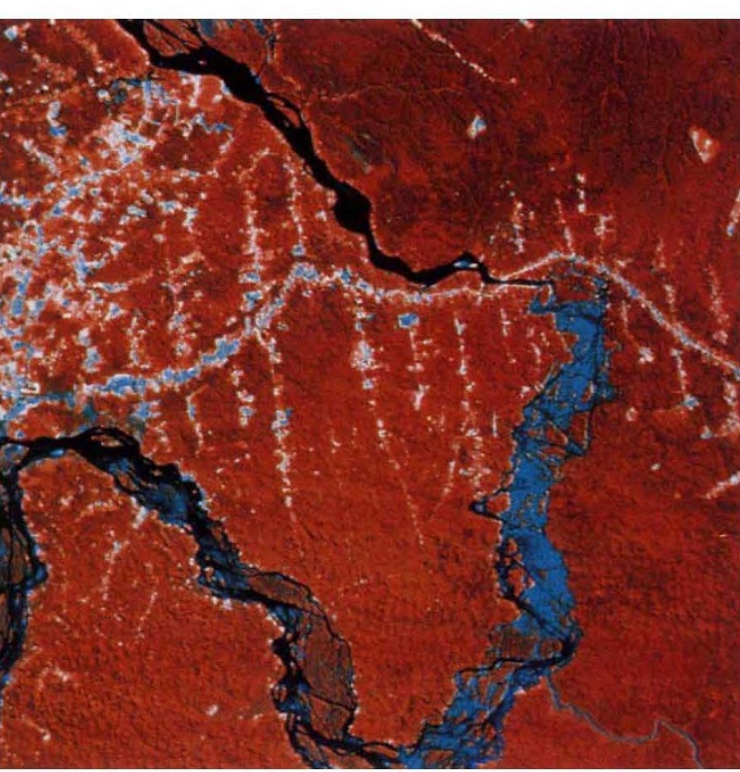

Landsat data - such as this Brazil deforestation image may soon cost a fraction of their current price.

EOSAT blames this situation on the loss of a Tracking and Data Relay Satellite in the 1986 explosion of the Challenger space shuttle, which left Landsat with only one relay satellite through which to send data, and officials say that it makes sense to collect data that it can sell. But critics say that it is another example of EOSAT's willingness to sacrifice science for profits.

Under the new agreement, the Landsat programme will be officially transferred from the National Oceanic and Atmospheric Administration to the DOD and NASA. A $\$ 20$-million annual subsidy to EOSAT to pay for the operation of Landsat 4 and 5 the only Landsat orbiters now aloft - will end, and researchers affiliated with the US global change research programme will be given access to data from Landsat 6 , to be launched early next year, essentially at cost. Commercial users and those who have not signed an agreement not to use the data for commercial purposes would continue to pay a higher fee. Data from Landsat 7, to be launched in 1997, will be sold at cost to all, including commercial users.

Although EOSAT will have to make Landsat 6 data available at cost to many of its users, despite its investment in building and launching the orbiter, it sees the agreement as an opportunity to save the overall programme, protect Landsat 7 and remove continuing threats of cancellation. EOSAT hopes to win over users who have been unwilling to invest in special equipment to process Landsat data given the programme's uncertain future. And although it does not advertise the fact, EOSAT also stands to benefit from a commitment by Congress to build Landsat 7 because its corporate parent, General Electric, is the odds-on favourite to get the contract.

The current bill, a compromise between legislation introduced earlier by US Representative George Brown (Democrat, California) and Senator Larry Pressler (Republican, South Dakota), was expected to be voted on this week in the Senate. But because it requires unanimous consent, a single opponent could derail the process until next year.

\section{Canada apologizes to physicist}

Quebec. The National Research Council (NRC) of Canada will not appeal against the decision of a tribunal of the Canadian Human Rights Commission that it discriminated against an Indian-born scientist, Chander Grover, on racial grounds (see Nature 359, 95; 1992).

Complying with the tribunal's orders, it sent letters of apology to Grover and to the Optical Society of America, before which Grover had been forced to cancel an invitation to speak. A cheque for $\$ 5,000$ and interest has been issued to Grover, and he has been appointed head of a 12-person optical components research group at the NRC.

The council says that its treatment of Grover was "not in any way based on race, colour or national origin but was the result of budget restrictions, shifts in research priorities and organizational restructuring". However, it has promised to review its policies and procedures relating to visible minority groups.

David Spurgeon 